phenomena said to accompany particular states of mental dissociation, might appropriately be taken up by a department of a university or other responsible scientific institution as subjects of post-graduate research. Since then we have received a circular relating to the formation of-a body with the title of the International Institute for Psychical Research, "for the furtherance of knowledge in regard to psychic phenomena". The president is Prof. Elliot Smith, and two of the vice-presidents are Prof. Julian Huxley and Prof. E. W. MacBride. The chairman of the executive committee is Mr. J. Arthur Findlay, a well-known business man in Glasgow, whose book "On the Edge of the Etheric", published last year, described a series of sittings with a Scottish "direct voice" medium. Judging from this book, Mr. Findlay has little conception of the critical attitude of science towards the evidence which he presents and the explanations he gives of the phenomena he describes. In the words of our reviewer of his book: "But from reading Mr. Findlay's records the scientific method might be thought not to exist. He seems to have no appreciation of the implications underlying many of his remarks; no desire to see the phenomena described in accurate and scientific terminology."

Perhaps the men of science who have become office bearers in the new organisation will be able to see that whatever investigations are undertaken are more in accord with what science demands than are those the explanations of which are accepted by Mr. Findlay. In any event, we need scarcely say that we do not regard the new body as satisfying the conditions of psychical research in a university or similar institution referred to in the leading article in our issue of December 23. Its aims and intentions do not seem to us to differ essentially from those of the Society for Psychical Research or from Mr. Harry Price's National Laboratory for Psychical Research.

\section{The Sea-Fish Commission}

Is accordance with the provisions of Section 5 of the Sea-Fishing Industry Act, 1933, the Secretary of State for Home Affairs, the Secretary of State for Scotland, and the Minister of Agriculture and Fisheries, have appointed a Sea-Fish Commission consisting of the following : Sir Andrew R. Duncan (chairman), Viscount Wolmer, M.P., Mr. Francis Beattie, Mr. Edwin Fisher, and Mr. Lawrence Neal. We note with regret that no man of science has found a place on this Commission, notwithstanding that some of its functions make scientific knowledge desirable-particularly piscicultural knowledge. To emphasise this desirability, it may be mentioned that the functions of the Committee will include the investigation of matters relating to the storage and treatment of fish after landing; and it is also inevit. able that pre-landing problems will call for investigation. It is most disappointing that the tendency to ignore scientific workers in the personnel of various kinds of commissions and committees should still persist ; it is the more difficult to understand when we remember that some members of the Cabinet have hitherto shown themselves to be scientifically minded.

\section{"Codex Sinaiticus"}

AN appeal to the public for the amount necessary to acquire the "Codex Sinaiticus" for the British Museum could not fail to moet with a generous response, especially when backed by the offer of the Government to provide an amount equal to that raised by public subscription up to a limit of $£ 50,000$. The unique place of the Bible in English life and literature renders it peculiarly appropriate that of the two oldest and most valuable sources of the Greek text, the "Sinaiticus" and the "Vaticanus", one should find an abiding resting place beside the later "Alexandrinus" in the British Museum, while the other lies in Rome. The price to be paid to Russia is undoubtedly large, even though the method of payment will lighten the burden; but it cannot be held too high for the enhanced prestige which it will confer on Britain's greatest national museum and the increased opportunities it will afford British scholarship in biblical studies, which already stands high. The crowds which thronged the British Museum in the days following the Christmas holidays, for a brief glimpse of the manuscript-by the end of the week there had been 20,000 visitors-and the readiness with which small subscriptions poured in, were an eloquent testimony of the extent to which the imagination of the public outside scholastic and learned circles had been touched by the interest of this document of almost unique importance in the history of civilisation.

\section{Archæological Exhibitions at the British Museum}

Two loan exhibitions were opened on January 4 in the Department of British and Medieval Antiquities, British Museum, at the head of the main staircase, containing respectively pre-Crag flints from Suffolk and palæoliths from the Raised Beach and Coombe Rock of Sussex. Mr. Reid Moir's exhibit is intended to show at least four periods, indicated by different patinations, for the rostro-carinates and other types from the Bone-bed at the base of the Crag; and one example in particular, which has a sandy deposit adhering, is held to prove its flaking prior to the Diestian deposits of the Lower Pliocene. Excavations by Mr. J. B. Calkin at Slindon Park, between Chichester and Arundel, have produced a series of worked flints which can be dated geologically, as some (mostly rolled) were found in the upper level of the Raised Beach there (surface-level $135 \mathrm{ft}$. O.D.), others on the top of the Beach and in the lower part of the Coombe Rock above it. Sufficient specimens have been found to prove that the Raised Beach dates from late St. Acheul times, and the Coombe Rock covered a Levallois working-floor as at Northfleet. The Raised Beach a little south, at a height of $80-90 \mathrm{ft}$. O.D., has not produced enough to establish its identity. 